\title{
ARTERIAL PATTERNS IN MITRAL STENOSIS
}

\author{
BY
}

\author{
CLIVE P. ABER, JOHN A. CAMPBELL, AND JOHN MEECHAM \\ From Liverpool Thoracic Surgical Centre and Department of Pathology, Broadgreen Hospital, Liverpool
}

Received June 13, 1962

Obliterative vascular damage in the small peripheral branches of the pulmonary artery is now a well-recognized feature of long-standing mitral stenosis. The small muscular pulmonary arteries and arterioles show varying degrees of medial and/or intimal thickening (Moschcowitz, 1927; Zeek, 1932; Brenner, 1935; Parker and Weiss, 1936; Larrabee, Parker, and Edwards, 1949; Heath and Whitaker, 1955). Over the past ten years, further histological observations (Gough, 1955; Short, 1956; Harrison, 1958; Parker, 1958) in addition to radiological and arteriographic studies (Goodwin, Steiner, and Lowe, 1952; Doyle et al., 1957; Simon, 1958) have drawn attention to the apparent differential distribution of these vascular lesions within the lungs in mitral stenosis, showing them to develop earlier and to be more advanced in the lower rather than the upper lobes. Quantitative evaluation of these lesions has been attempted by several workers on both autopsy and biopsy material (Larrabee et al., 1949; Graham et al., 1951; Enticknap, 1953; Heath and Whitaker, 1955). These studies have usually consisted of measurements either of the thickness of the walls of these small arterial vessels or of their lumen to wall ratio.

Hæmodynamic observations suggest that the severity and distribution of this structural vascular damage and the radiological vascular patterns that are found in mitral stenosis may parallel changes in both the pulmonary arterial pressure and the pulmonary vascular resistance (Bayliss, Etheridge, and Hyman, 1950; Taquini et al., 1953; Davies et al., 1953, Whitaker and Lodge, 1954; Steiner and Goodwin, 1954).

It therefore seemed worth while exploring the relation, if any, of these radiological pulmonary vascular changes to (a) the mean pulmonary arterial pressure and (b) the severity of the pathological changes in the small branches of the pulmonary artery, in patients with mitral stenosis submitted to mitral valvotomy.

\section{SUBJECTS AND METHODS}

The study included 79 patients all of whom had dominant mitral stenosis, as judged from clinical, radiological, electrocardiographic, and phonocardiographic studies. The exact nature of the mitral valve lesion was determined on cardiotomy. The patients were graded according to their functional capacity (exercise tolerance) using the New York Heart Association Classification (1945).

Sixty-two small wedge biopsy specimens were obtained from the anterior portion of the lingula at thoracotomy. Each was placed directly into 10 per cent formalin fixative and embedded in paraffin wax. Sections were cut and stained as follows.

For general examination hæmotoxylin and eosin was used; and Weigert's elastic stain counterstained with van Gieson's connective tissue stain was used for vascular measurements.

All sections were examined and assessed by two of the authors (C. P. A. and J. A. C.) independently. When there was disagreement regarding evaluation of any section, it was reviewed by both authors together and a final grading established.

The following quantitative microscopic observations were made on each biopsy specimen.

The thickness of the media in the small muscular pulmonary arteries $(\mathrm{M} / \mathrm{D} \%)$ was expressed as a percentage of the external diameter of the vessel by the method of Heath and Whitaker (1955). 
The lumen to wall ratio: the mean value for this was obtained for both the small muscular pulmonary arteries $(\mathrm{L}: \mathrm{Wa})$, and the pulmonary arterioles $(\mathrm{L}: \mathrm{Wb})$ in each section, using the method described by Kernohan, Anderson, and Keith (1929).

The severity of intimal thickening was evaluated for small muscular pulmonary arteries and arterioles separately, according to the scheme presented in Table I. Marks were awarded as indicated (Fig. 1-8). When, in any section, the intimal thickening appeared to be half of one grade and half of the next grade,

TABLE I

Assessment of Degree of Intimal Thickening in Pulmonary Muscular Arteries and Arterioles in Mitral STENOSIS

\begin{tabular}{c|l}
\hline \multicolumn{1}{c}{ Grade } & \multicolumn{1}{c}{ Definition } \\
\hline $\begin{array}{c}0 \\
\text { marks }=0)\end{array}$ & Normal-no intimal thickening \\
\hline $\begin{array}{c}1 \\
(\text { marks }=1)\end{array}$ & $\begin{array}{l}\text { Slight but certain intimal thickening in at least half the vessels in } \\
\text { the section }\end{array}$ \\
\hline $\begin{array}{c}2 \\
(\text { marks }=2)\end{array}$ & $\begin{array}{l}\text { When at least half the vessels showed moderate thickening of the } \\
\text { intima, but this did not exceed half the diameter of the lumen }\end{array}$ \\
\hline $\begin{array}{l}3 \\
(\text { marks = 3) }\end{array}$ & $\begin{array}{l}\text { Severe thickening of the intima, exceeding half the diameter of } \\
\text { lumen in at least half the vessels in the section }\end{array}$ \\
\hline
\end{tabular}

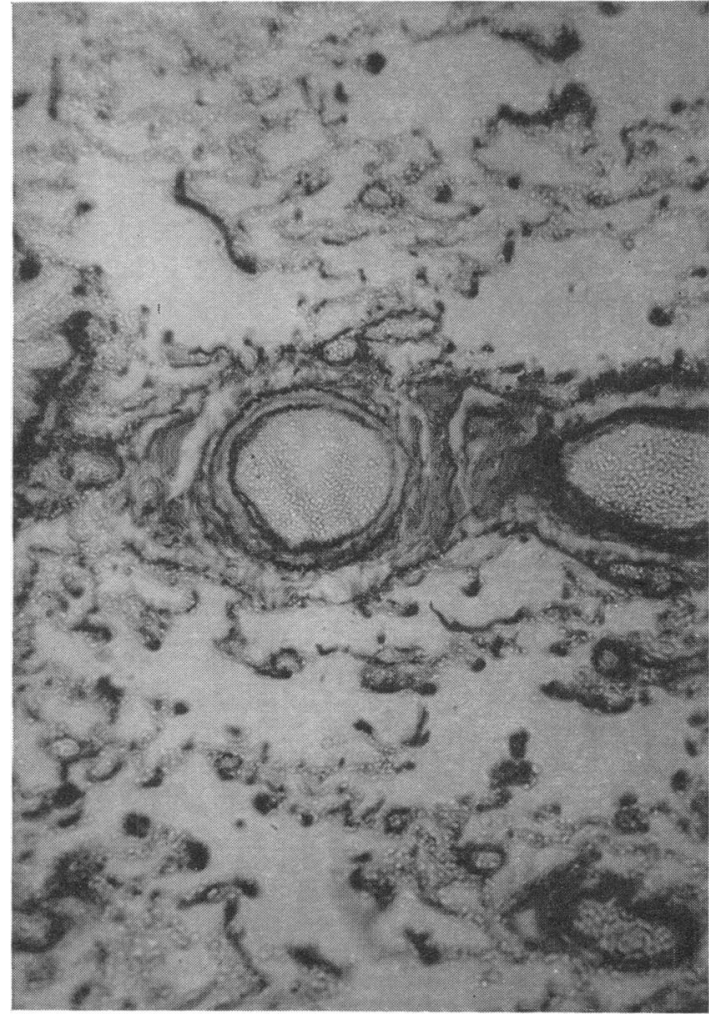

FIG. 1.-A normal muscular pulmonary artery(Weigert's elastic and Van Gieson: $\times 63$ ).

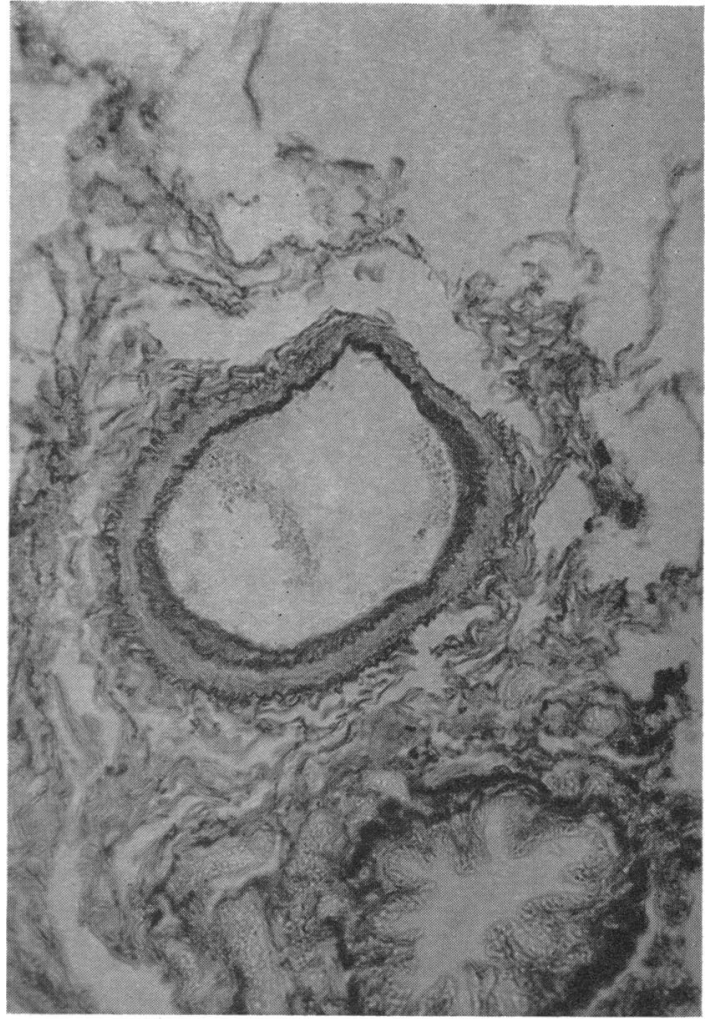

FIG. 2.-Grade 1 intimal thickening in a muscular pulmonary artery-(Weigert's elastic and Van Gieson: $\times 63$ ). 


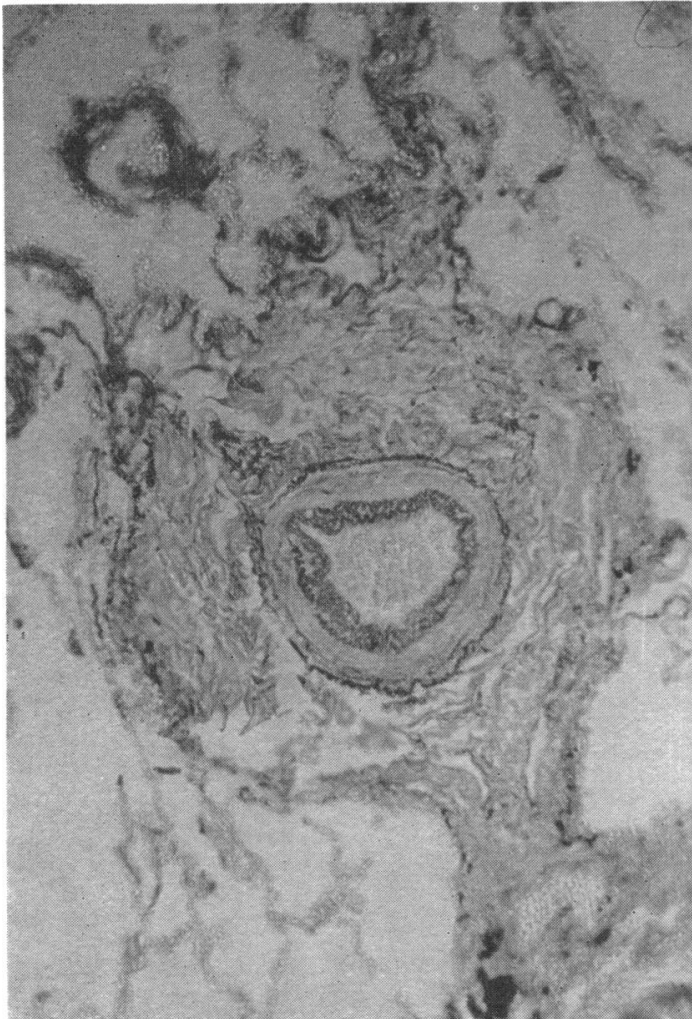

FIG. 3.-Grade 2 intimal thickening in a muscular pulmonary artery-(Weigert's elastic and Van Gieson: $\times 63)$.

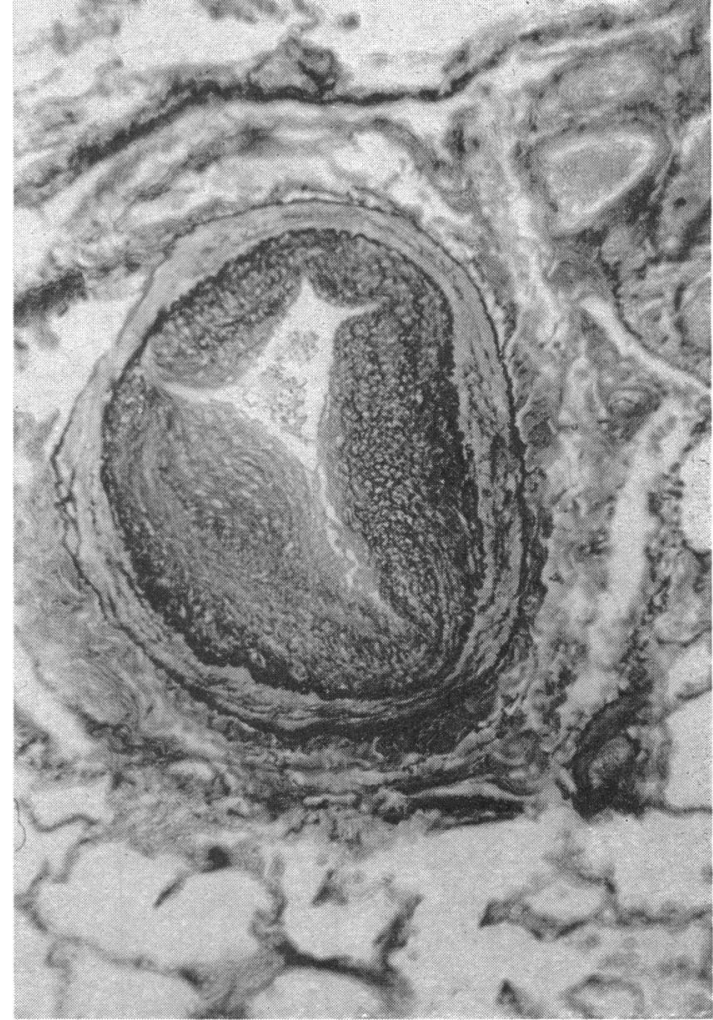

Fig. 4.-Grade 3 intimal thickening in a muscular pulmonary artery-(Weigert's elastic and Van Gieson: $\times 63)$.

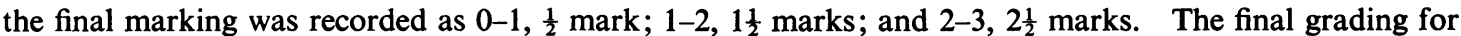
each section was made by the addition of the marks gained by the muscular pulmonary arteries and the pulmonary arterioles separately.

At thoracotomy direct mean pulmonary arterial and left atrial pressures were obtained on 73 patients through a 21-gauge needle connected to a saline manometer by a metre of hardened nylon tubing of $1.5 \mathrm{~mm}$. bore.

The pulmonary artery and its branches were assessed radiologically. Postero-anterior chest radiographs of each patient were viewed by two of the authors (C. P. A. and J. M.). Each author assessed the films independently with regard to the features outlined below. When there was disagreement over grading these radiological changes, the film was viewed by both authors together and a final grading established.

(a) Enlargement of the main pulmonary artery segment was assessed according to the following criteria.

Grade 1 (Fig. 9). Normal or slight enlargement of the main pulmonary artery segment-when a tangential line (T) drawn from the aortic knuckle to the main mass of the left cardiac border falls clear of the pulmonary artery by more than $2 \mathrm{~mm}$.

Grade 2 (Fig. 10). Moderate enlargement of the main pulmonary artery segment, forming a straight left cardiac border-the line (T) touches the pulmonary artery (allowing $\pm 2 \mathrm{~mm}$. variation in both directions from this line).

Grade 3 (Fig. 11). Great enlargement of the main pulmonary artery segment-the main pulmonary artery extends beyond the left cardiac border by more than $2 \mathrm{~mm}$., and the line (T) crosses it.

(b) Peripheral Arterial Pattern. The degree of attenuation or "cut off" in the small peripheral branches of the pulmonary artery was assessed as follows.

Grade 1 (Fig. 12). Normal or slight peripheral attenuation or "cut off" involving the distal third of the arteries to the lower lobes. 


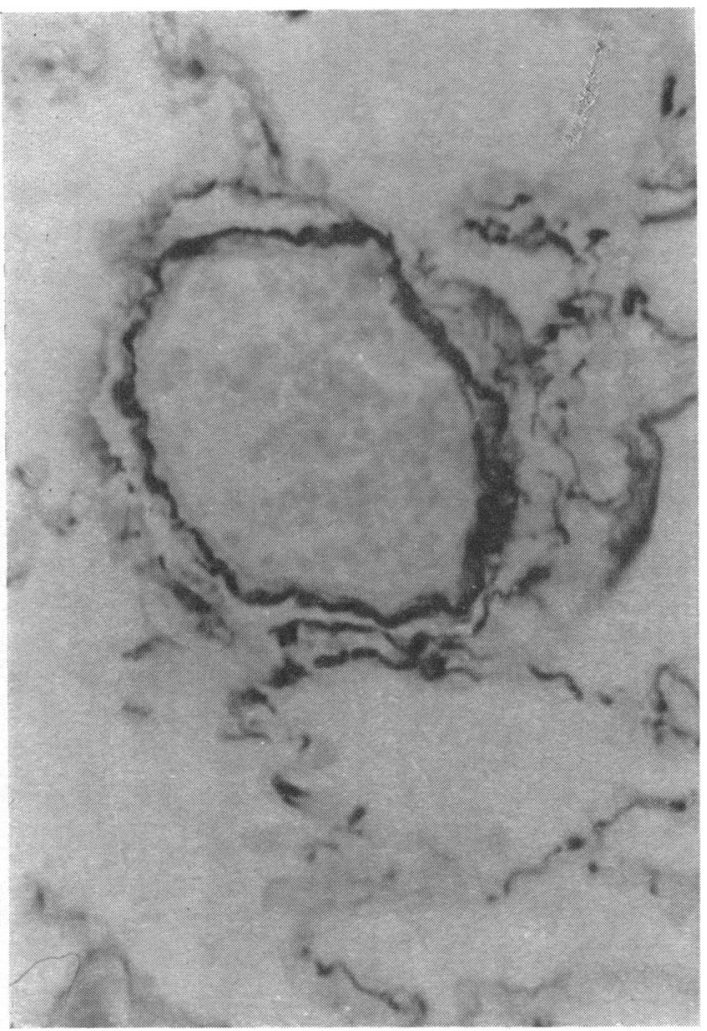

FIG. 5.-A normal pulmonary arteriole-(Weigert's elastic and Van Gieson: $\times 254$ ).

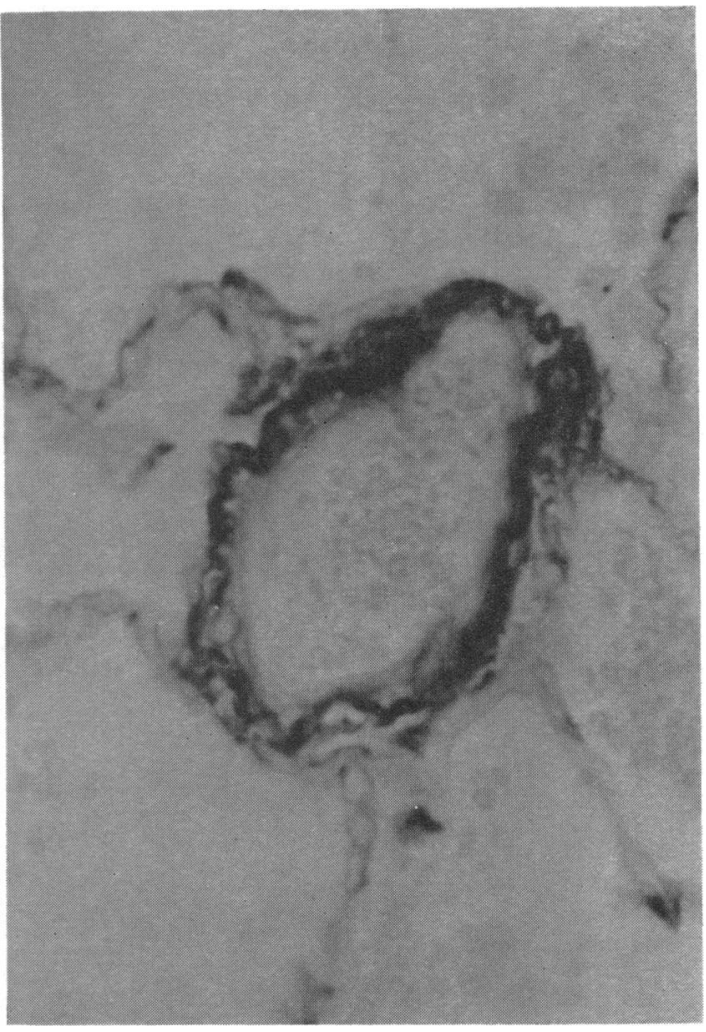

FIG. 6.-Grade 1 intimal thickening in a pulmonary arteriole-(Weigert's elastic and Van Gieson: $\times 254)$.

Grade 2 (Fig. 13). One-half to two-thirds peripheral attenuation or "cut off" in the lower lobes.

Grade 3 (Fig. 14). Peripheral "cut off" involving the whole length of the arteries from the hilum. The regular vessels forming the hilar tail are completely absent or alternatively fringe-like streaks may be seen emerging from the hilum.

\section{RESULTS}

Enlargement of the Main Pulmonary Artery Segment. In general the greater the degree of functional incapacity, the larger was the main pulmonary segment (Fig. 15). This segment also increased in size as the mean pulmonary arterial pressure rose. Moderate or severe pulmonary hypertension

TABLE II

Relation of Pathological Changes in Pulmonary Muscular Arteries and Arterioles to Enlargement of Main Pulmonary Artery Segment in Mitral Stenosis

\begin{tabular}{|c|c|c|c|c|c|c|c|c|}
\hline \multirow{3}{*}{\multicolumn{2}{|c|}{$\begin{array}{l}\text { Enlargement of main pulmonary } \\
\text { artery segment }\end{array}$}} & \multicolumn{4}{|c|}{ Changes in pulmonary muscular arteries } & \multirow{2}{*}{\multicolumn{3}{|c|}{$\frac{\text { Changes in pulmonary arterioles }}{\mathrm{L}: \mathrm{W} \text { ratio }}$}} \\
\hline & & \multirow{2}{*}{$\begin{array}{c}\mathrm{M} / \mathrm{D} \% \\
10 \% \text { or }> \\
\end{array}$} & \multicolumn{3}{|c|}{$\mathrm{L}: \mathrm{W}$ ratio } & & & \\
\hline & & & $<9: 1$ & $<5: 1$ & $<4: 1$ & $<6 \cdot 6: 1$ & $<5: 1$ & $<4: 1$ \\
\hline $\begin{array}{l}\text { Grade } 1 \text { ( } 27 \text { X-rays) } \\
\text { Grade } 2 \text { ( } 24 \text { X-rays) } \\
\text { Grade } 3 \text { (11 X-rays) }\end{array}$ & $\begin{array}{l}\cdots \\
\cdots \\
\cdots\end{array}$ & $\begin{array}{l}25 \% \\
60 \% \\
78 \%\end{array}$ & $\begin{array}{r}65 \% \\
96 \% \\
100 \%\end{array}$ & $\begin{array}{l}34 \% \\
72 \% \\
78 \%\end{array}$ & $\begin{array}{l}34 \% \\
56 \% \\
56 \%\end{array}$ & $\begin{array}{r}61 \% \\
84 \% \\
100 \%\end{array}$ & $\begin{array}{l}21 \% \\
64 \% \\
89 \%\end{array}$ & $\begin{array}{l}10 \% \\
56 \% \\
64 \%\end{array}$ \\
\hline
\end{tabular}




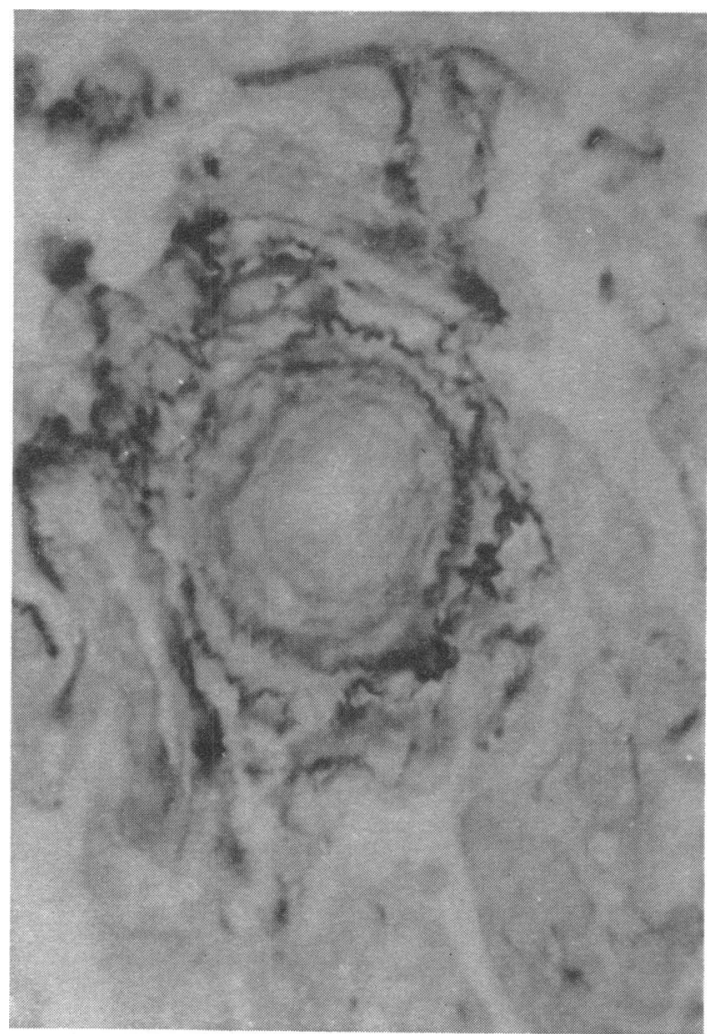

Fig. 7.-Grade 2 intimal thickening in a pulmonary arteriole-(Weigert's elastic and Van Gieson: $\times 254$ ).

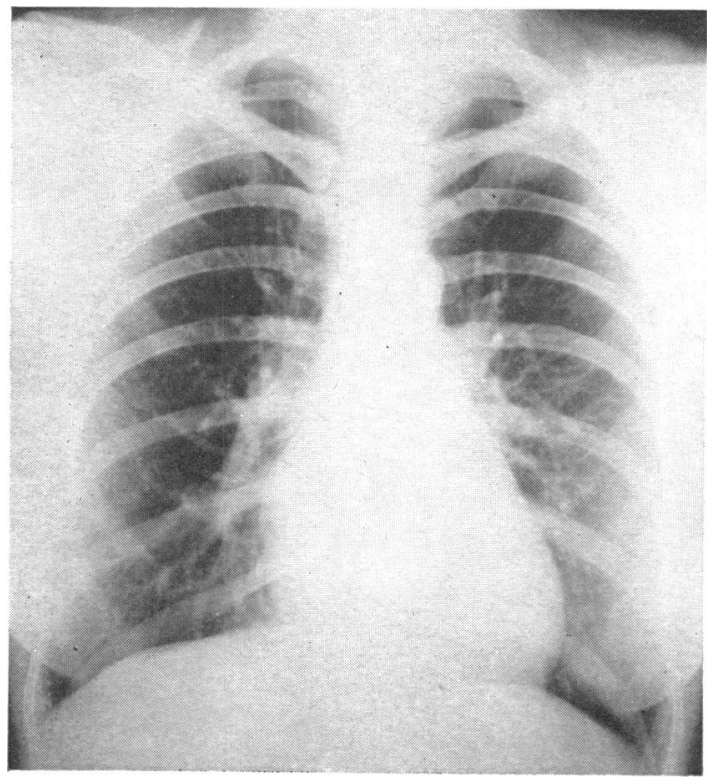

FIG. 9.-Grade 1 main pulmonary artery segment.

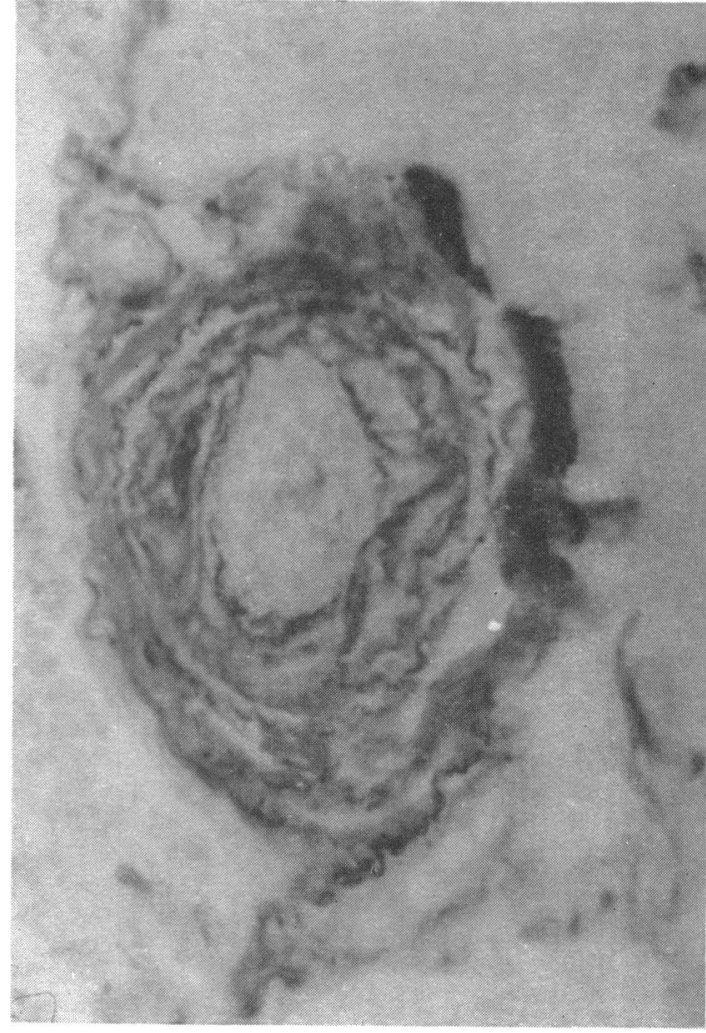

Fig. 8.-Grade 3 intimal thickening in a pulmonary arteriole-(Weigert's elastic and Van Gieson: $\times 254$ ).

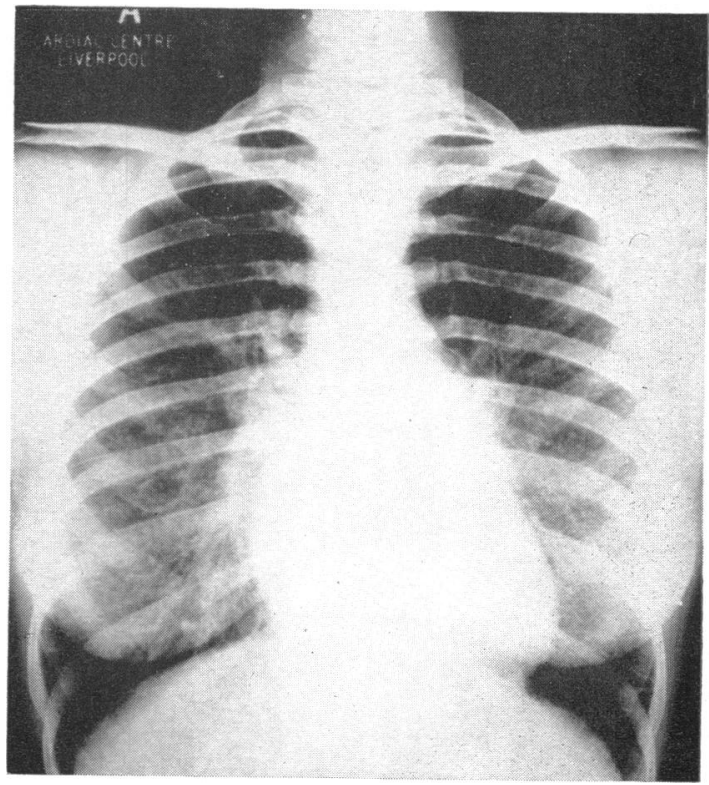

Fig. 10.-Grade 2 main pulmonary artery segment. 


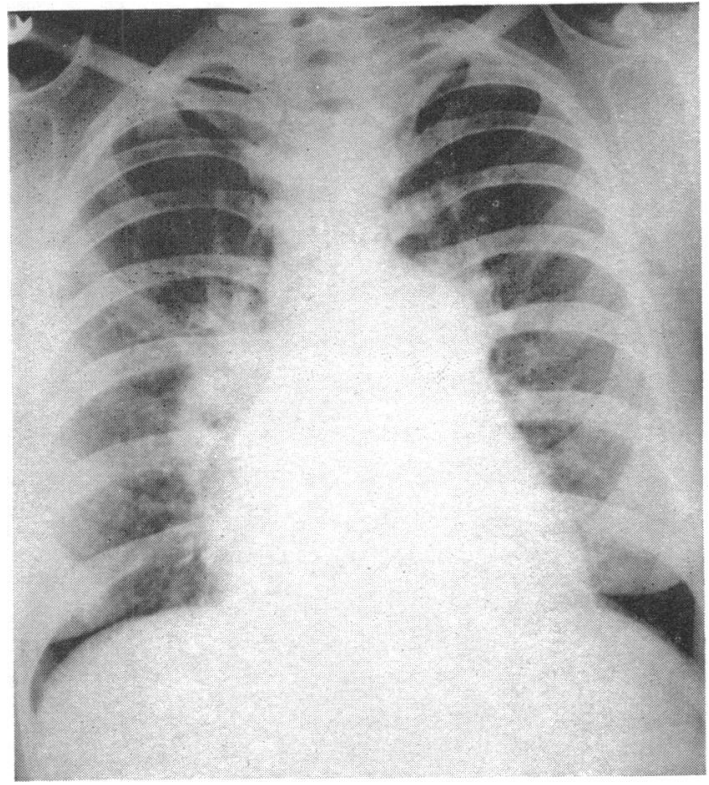

FIG. 11.-Grade 3 main pulmonary artery segment.

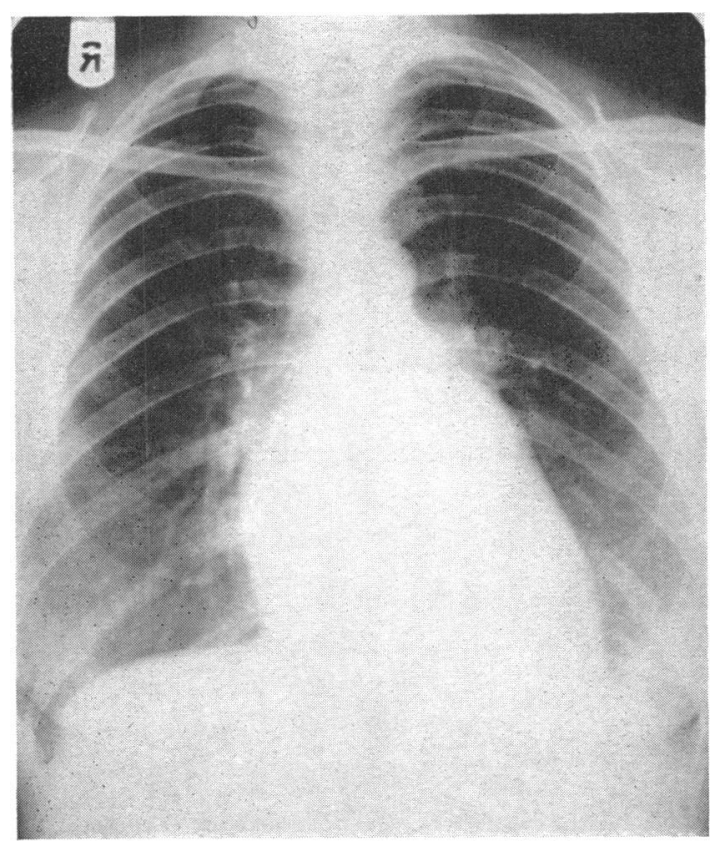

Fig. 13.-Grade 2. Peripheral arterial pattern.

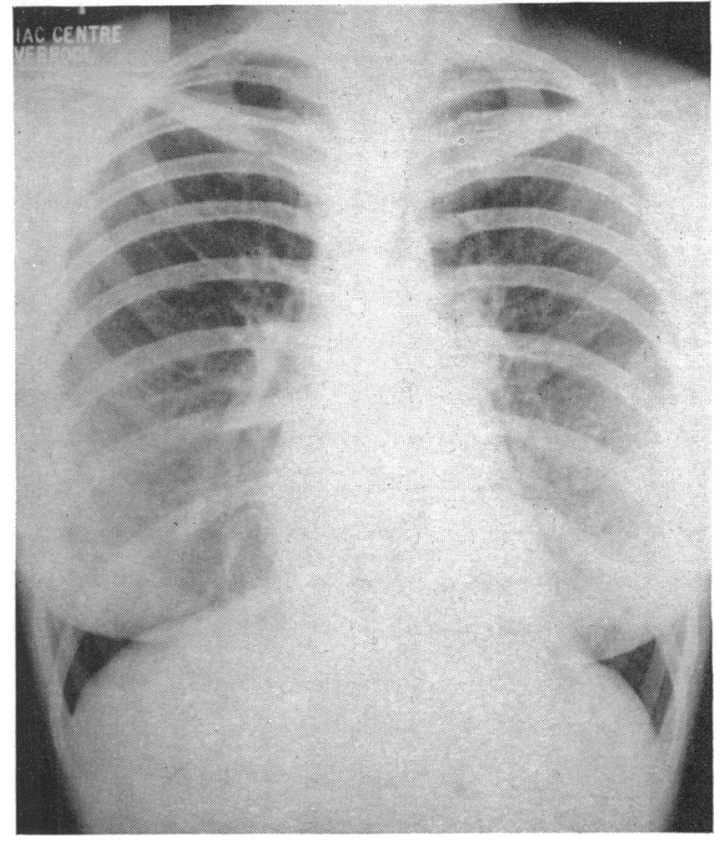

Fig. 12.-Grade 1. Peripheral arterial pattern.

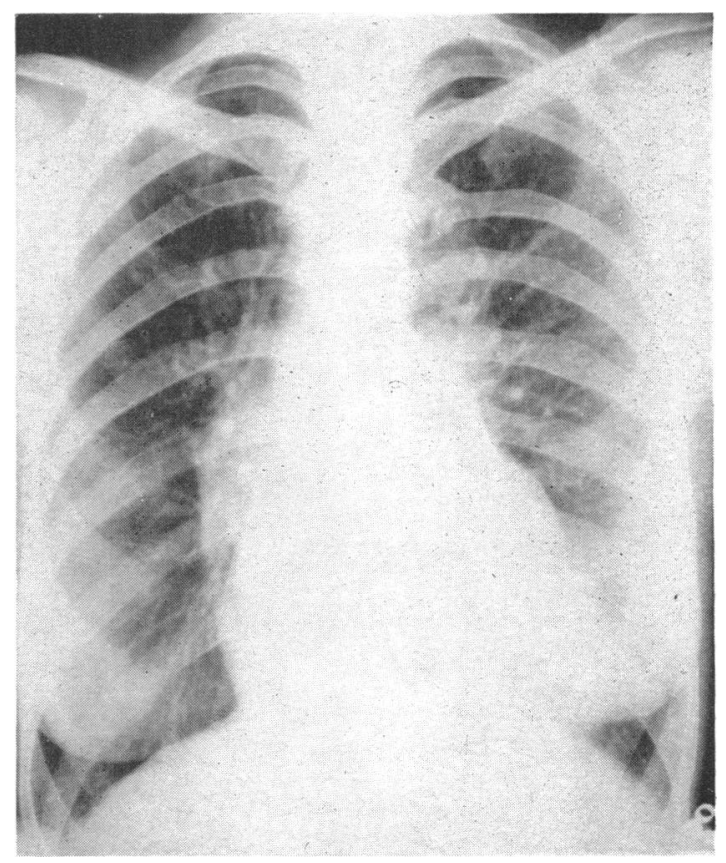

FIG. 14.-Grade 3. Peripheral arterial pattern. 
was an invariable accompaniment of Grade 2 and 3 enlargement (Table III). The correlation between the pathological measurements and radiological enlargement of the main pulmonary artery segment was reasonably good (Table II). No relation, however, was observed between the severity of intimal thickening and the three grades of radiological enlargement of the main pulmonary artery segment.

The Peripheral Arterial Pattern. The more severe the radiological changes in the peripheral branches of the pulmonary artery, the greater was the functional incapacity, the higher the mean pulmonary arterial pressure and the more severe the obliterative vascular damage in the muscular

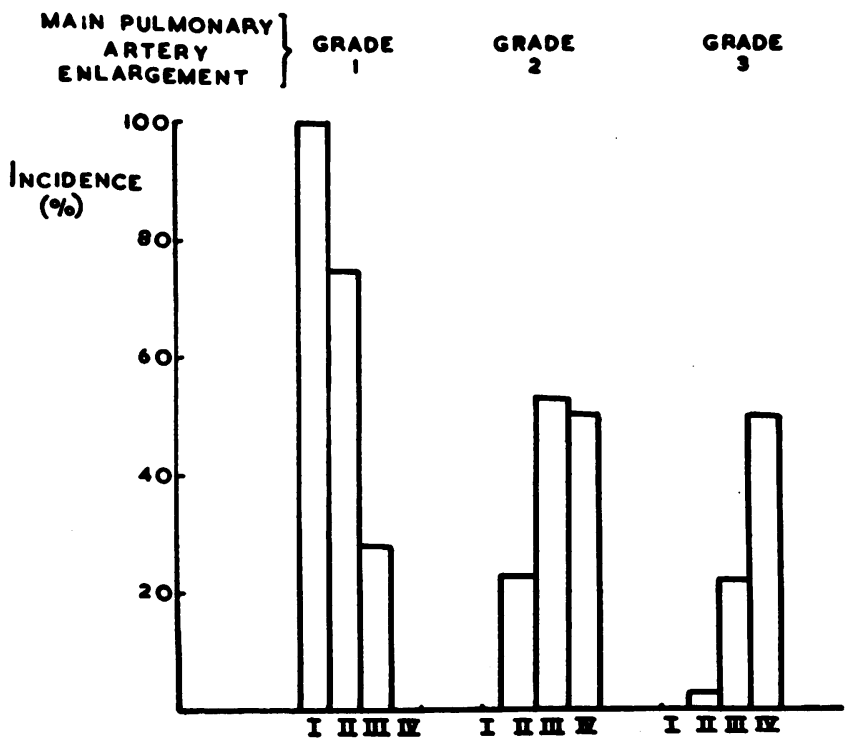

Fig. 15.-Enlargement of the main pulmonary artery segment in relation to the grade of functional incapacity (I-IV) in mitral stenosis.

TABLE III

Relation of Mean Pulmonary Artery Pressure (P.Am) to (a) Enlargement of Main Pulmonary Artery Segment and $(b)$ Peripheral Arterial Pattern in Mitral Stenosis

\begin{tabular}{|c|c|c|c|c|c|c|}
\hline \multicolumn{2}{|c|}{ Radiological changes } & \multirow{2}{*}{$\begin{array}{l}\text { P.Am. for } \\
\text { each Grade }\end{array}$} & \multirow{2}{*}{$\begin{array}{l}\text { Range of } \\
\text { P.Am. }\end{array}$} & \multicolumn{3}{|c|}{$\begin{array}{l}\text { Incidence }(\%) \text { of radiological changes in } \\
\text { certain ranges of P.Am. }\end{array}$} \\
\hline & & & & $>30 \mathrm{~mm} . \mathrm{Hg}$ & $>40 \mathrm{~mm} . \mathrm{Hg}$ & $>50 \mathrm{~mm} . \mathrm{Hg}$ \\
\hline $\begin{array}{l}\text { Enlargement of the } \\
\text { main pulmonary } \\
\text { artery segment }\end{array}$ & $\begin{array}{l}\text { Grade 1 } \\
\text { (36 X-rays) } \\
\text { Grade 2 } \\
\text { (26 X-rays) } \\
\text { Grade 3 } \\
\text { (11 X-rays) }\end{array}$ & $\begin{array}{l}29 \cdot 0 \\
44 \cdot 0 \\
56 \cdot 0\end{array}$ & $\begin{array}{l}13-50 \\
29-90 \\
30-85\end{array}$ & $\begin{array}{r}30 \cdot 5 \\
69 \cdot 5 \\
100 \cdot 0\end{array}$ & $\begin{array}{l}16 \cdot 7 \\
42 \cdot 0 \\
64 \cdot 0\end{array}$ & $\begin{array}{c}0 \\
31.0 \\
54.5\end{array}$ \\
\hline $\begin{array}{l}\text { Peripheral arterial } \\
\text { pattern }\end{array}$ & $\begin{array}{l}\text { Grade } 1 \\
\text { (49 X-rays) } \\
\text { Grade } 2 \\
\text { (20 X-rays) } \\
\text { Grade } 3 \\
\text { (4 X-rays) }\end{array}$ & $\begin{array}{l}33 \cdot 5 \\
46 \cdot 0 \\
60 \cdot 0\end{array}$ & $\begin{array}{r}13-90 \\
27-85 \\
45-70\end{array}$ & $\begin{array}{r}49 \cdot 0 \\
75 \cdot 0 \\
100 \cdot 0\end{array}$ & $\begin{array}{r}17 \cdot 0 \\
55 \cdot 0 \\
100 \cdot 0\end{array}$ & $\begin{array}{r}9 \cdot 8 \\
35 \cdot 0 \\
75 \cdot 0\end{array}$ \\
\hline
\end{tabular}


pulmonary arteries and arterioles (Fig. 16; Tables II and IV). It was observed that the severity of intimal thickening bore a much closer relation to the peripheral arterial pattern than it did to enlargement of the main pulmonary artery segment (Table V).

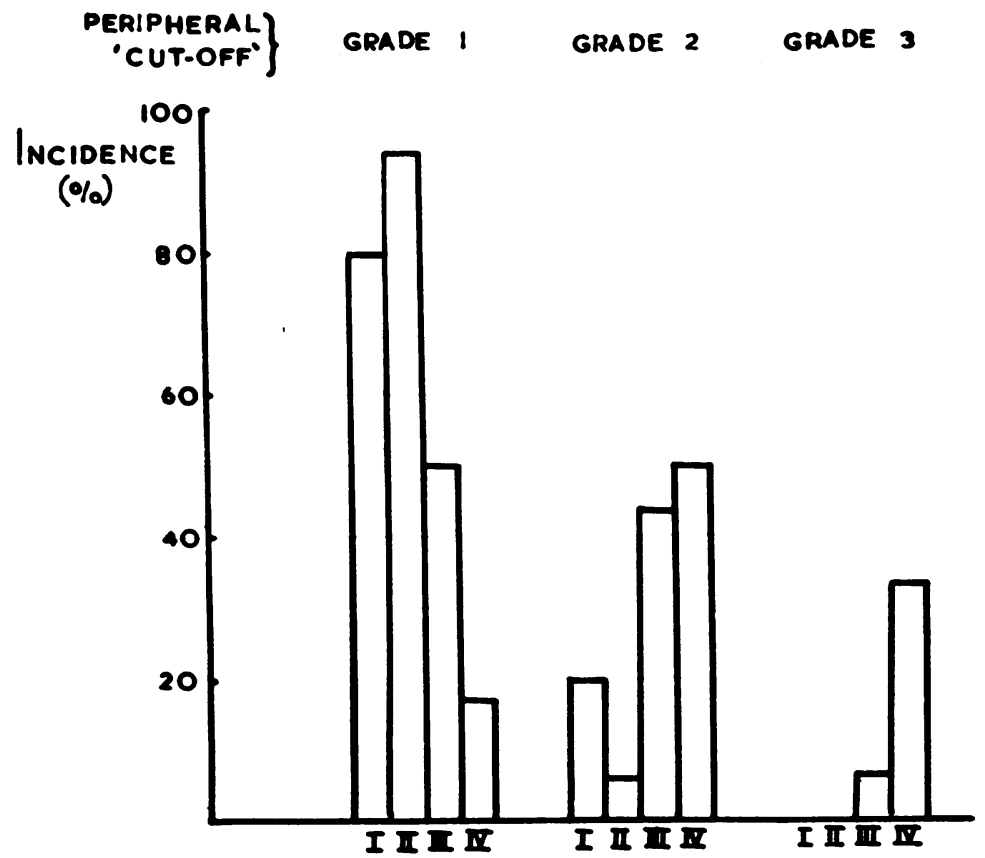

FIG. 16. - The peripheral arterial pattern in relation to the grade of functional incapacity (I-IV) in mitral stenosis.

TABLE IV

Relation of Pathological Changes in Pulmonary Muscular Arteries and Arterioles to Peripheral Arterial PatTern in Mitral Stenosis

\begin{tabular}{|c|c|c|c|c|c|c|c|c|c|}
\hline \multirow{3}{*}{\multicolumn{3}{|c|}{ Peripheral arterial pattern }} & \multicolumn{4}{|c|}{ Changes in pulmonary muscular arteries } & \multirow{2}{*}{\multicolumn{3}{|c|}{$\frac{\text { Changes in pulmonary arterioles }}{\text { L:W ratio }}$}} \\
\hline & & & \multirow{2}{*}{$\frac{\mathrm{M} / \mathrm{D} \%}{10 \% \text { or }>}$} & \multicolumn{3}{|c|}{ L:W ratio } & & & \\
\hline & & & & $<9: 1$ & $<5: 1$ & $<4: 1$ & $<6 \cdot 6: 1$ & $<5: 1$ & $<4: 1$ \\
\hline $\begin{array}{l}\text { Grade } 1 \text { (41 X-rays) } \\
\text { Grade } 2 \text { (17 X-rays) } \\
\text { Grade } 3 \text { (4 X-rays) }\end{array}$ & $\begin{array}{l}\cdots \\
\cdots \\
\cdots\end{array}$ & $\begin{array}{l}\cdots \\
\cdots \\
\cdots\end{array}$ & $\begin{array}{r}29 \% \\
76 \% \\
100 \%\end{array}$ & $\begin{array}{r}74 \% \\
100 \% \\
100 \%\end{array}$ & $\begin{array}{l}31 \% \\
88 \% \\
100 \%\end{array}$ & $\begin{array}{l}29 \% \\
84 \% \\
100 \%\end{array}$ & $\begin{array}{l}66 \% \\
100 \% \\
100 \%\end{array}$ & $\begin{array}{r}24 \% \\
91 \% \\
100 \%\end{array}$ & $\begin{array}{l}12 \% \\
89 \% \\
75 \%\end{array}$ \\
\hline
\end{tabular}

\section{Discussion}

These results do not demonstrate a linear relation between the radiological vascular changes and the hæmodynamic disturbances in mitral stenosis. However, they do show in general that the larger the main pulmonary artery segment and the greater the degree of attenuation or "cut off" in the peripheral branches of the pulmonary artery, the higher the mean pulmonary arterial pressure. This confirms the ideas of several previous workers who suggested that the enlargement of the pulmonary artery was a response to pulmonary hypertension (Bayliss et al., 1950; Taquini et al., 1953; Whitaker and Lodge, 1954). Similarly, the present observations substantiate the work of 
TABLE V

Frequency of Severe Intimal Thickening in Pulmonary Muscular Arteries and Arterioles in Relation to Peripheral Arterial Pattern in Mitral Stenosis

\begin{tabular}{|c|c|c|}
\hline \multirow[t]{2}{*}{ Peripheral arterial pattern } & \multicolumn{2}{|c|}{$\begin{array}{c}\text { Severity of intimal thickening } \\
\text { (marks) }\end{array}$} \\
\hline & 3.0 or more & 4.0 or more \\
\hline $\begin{array}{l}\text { Grade } 1 \text { (41 X-rays) } \\
\text { Grade } 2 \text { (17 X-rays) } \\
\text { Grade } 3 \text { (4 X-rays) }\end{array}$ & $\begin{array}{l}1(2 \cdot 4 \%) \\
16(94 \%) \\
4(100 \%)\end{array}$ & $\begin{array}{c}0 \\
12(70 \cdot 5 \%) \\
4(100 \%)\end{array}$ \\
\hline
\end{tabular}

Davies et al. (1953) and Steiner and Goodwin (1954), which showed that the size of the main pulmonary artery correlates well with the degree of pulmonary hypertension, when this is either moderate or severe.

The present findings also demonstrate that there is a reasonable correlation between the severity of the pathological changes in the small pulmonary arteries in the lingula and the radiological vascular patterns in mitral stenosis. Since, however, this vascular damage is greater in the lingula and precedes vascular damage elsewhere in the lungs, such a relation may not hold for biopsy material obtained from other areas of the lungs (Goodale et al., 1955; Doyle et al., 1957; Evans and Short, 1957; Harrison, 1960).

This method of radiological assessment offers a fairly simple and accurate method of evaluating pulmonary arterial hypertension and arterial vascular damage in mitral stenosis, without resorting to the potentially more dangerous technique of cardiac catheterization. It is suggested that information obtained in this way would allow more accuracy when attempting to predict the likely immediate and long-term benefit from mitral valvotomy.

\section{SUMMARY}

The hæmodynamic and pathological significance of radiological enlargement of the main pulmonary artery segment and attenuation of the peripheral arterial pattern has been investigated in 79 patients with mitral stenosis. Moderate or severe pulmonary arterial hypertension can be accurately predicted after studying these radiological vascular patterns. Similarly, the severity of the structural damage within the small peripheral branches of the pulmonary artery is reflected in these radiological changes.

Our thanks are due to the surgeons and physicians of the Liverpool Thoracic Surgical and Liverpool Cardiac Centres, for allowing us access to their patients; and to Dr. W. S. Sutton, Dr. Colin Ogilvie, and Dr. F. Whitwell for their advice and encouragement throughout this work. Finally, we should like to record our gratitude to the technical staff in the Respiratory and Pathology Laboratories, Broadgreen Hospital.

\section{REFERENCES}

Bayliss, R. I. S., Etheridge, M. J., and Hyman, A. L. (1950). Lancet, 2, 889.

Brenner, O. (1935). Arch. intern. Med., 56, 1189.

Davies, L. G., Goodwin, J. F., Steiner, R. E., and Van Leuven, B. D. (1953). Brit. Heart J., 15, 393.

Doyle, A. E., Goodwin, J. F., Harrison, C. V., and Steiner, R. E. (1957). Brit. Heart J., 19, 353.

Enticknap, J. B. (1953). J. clin. Path., 6, 84.

Evans, W., and Short, D. S. (1957). Brit. Heart J., 19, 457.

Goodale, F., Jr., Sanchez, G., Friedlich, A. L., Jr., Scannell, J. G., and Myers, G. S. (1955). New Engl. J. Med., 252, 979.

Goodwin, J. F., Steiner, R. E., and Lowe, K. G. (1952). J. Fac. Radiol. (Lond.), 4, 21.

Gough, J. (1955). Lancet, 1, 161.

Graham, G. K., Taylor, J. A., Ellis, L. B., Greenberg, D. J., and Robbins, S. L. (1951). A.M.A. Arch. intern. Med., 88, 532.

Harrison, C. V. (1958). Brit. J. Radiol., 31, 217.

(1960). Recent Advances in Pathology, 7th ed. Churchill, London. 
Heath, D., and Whitaker, W. (1955). J. Path. Bact., 70, 291.

Kernohan, J. W., Anderson, E. W., and Keith, N. M. (1929). Arch. intern. Med., 44, 395.

Larrabee, W. F., Parker, R. L., and Edwards, J. E. (1949). Proc. Mayo Clin., 24, 316.

Moschcowitz, E. (1927). Amer. J. med. Sci., 174, 388.

Parker, F., and Weiss, S. (1936). Amer. J. Path., 12, 573.

Parker, R. A. (1958). Stanf. med. Bull., 16, 87.

Short, D. S. (1956). Brit. Heart J., 18, 233.

Simon, M. (1958). J. Fac. Radiol. (Lond.), 9, 25.

Steiner, R. E., and Goodwin, J. F. (1954). J. Fac. Radiol. (Lond.), 5, 167.

Taquini, A. C., Lozada, B. B., Donaldson, R. J., D'Aiutolo, R. E. H., and Ballina, E.'S. (1953). Amer. Heart J., 46, 639.

Whitaker, W., and Lodge, T. (1954). J. Fac. Radiol. (Lond.), 5, 182.

Zeek, P. (1932). Amer. J. med. Sci., 184, 356. 